\title{
DIGITALCOMMONS
}

@WAYNESTATE-

Wayne State University

$1-1-2011$

\section{Letter of Credit Litigation under UCC Article 5: A Case of Statutory Preemption}

John F. Dolan

Wayne State University, j.dolan@wayne.edu

\section{Recommended Citation}

John F. Dolan, Letter of Credit Litigation under UCC Article 5: A Case of Statutory Preemption, 57 Wayne L. Rev. 1269 (2011). Available at: http://digitalcommons.wayne.edu/lawfrp/70

This Article is brought to you for free and open access by the Law School at DigitalCommons@WayneState. It has been accepted for inclusion in Law Faculty Research Publications by an authorized administrator of DigitalCommons@WayneState. 


\title{
LETTER OF CREDIT LITIGATION UNDER UCC ARTICLE 5: A CASE OF STATUTORY PREEMPTION
}

\author{
JOHN F. DOLAN ${ }^{\dagger}$
}

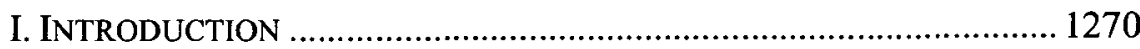

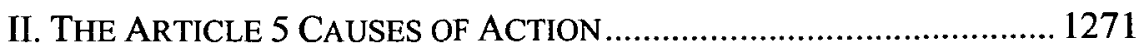

III. THE ECONOMIC LOSS DOCTRINE AND SIMILAR DOCTRINES ......... 1274

A. In Sale of Goods Transactions .............................................. 1274

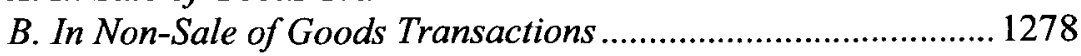

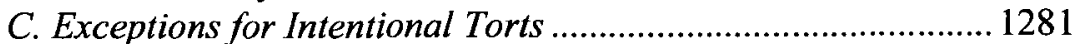

D. Conclusions Regarding the Doctrine's Policies........................ 1283

IV. THE UNIQUE NATURE OF THE LETTER OF CREDIT......................... 1284

V. BENEFICIARY CAUSES OF ACTION …………….......................... 1286

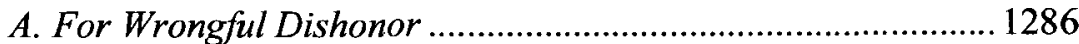

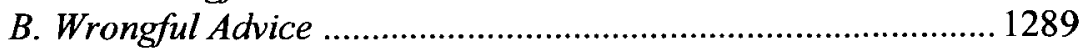

VI. APPLICANT CAUSES OF ACTION ............................................... 1290

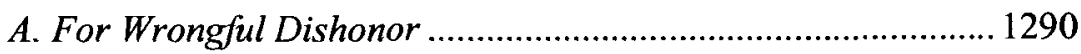

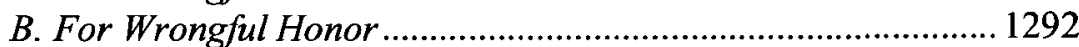

C. For Breach of Warranty ........................................................ 1294

VII. ISSUER AND THIRD PARTY CAUSES OF ACTION ............................ 1296

A. Banks in Their Various Letter of Credit Transaction Roles .... 1297

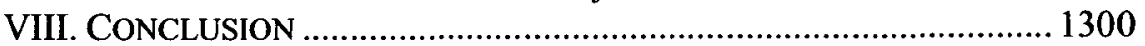

In this article, Professor Dolan maintains that UCC Article 5 fashions a comprehensive remedy scheme for recurring damages claims in letter of credit litigation. That scheme, he contends, is upset by the introduction of most common law causes of action in Article 5 litigation. He concludes, therefore, that courts should not entertain those common law claims, which he sees as destructive of letter of credit law and of the unique commercial nature of letters of credit. Using the economic loss

$†$ Distinguished Professor, Wayne State University Law School. L.L.B., 1965, University of Illinois College of Law. An early version of this paper was the subject of a presentation at a program on Commercial Law at China University of Political Science and Law in Beijing on May 11, 2011. Thanks to those who attended for their questions and comments, and special thanks to Dean Xiang Gao for arranging the presentation and to Liu Bin, who gave a summary of it to the assembly in his native tongue. An even earlier version was presented to the William \& Mary School of Law faculty on January 29,2009 . Thanks to those who attended for their comments and questions, especially Eric Kades and Lan Cao, and also special thanks to Peter Alces. Finally, thanks to Richard Dole and recognition to Peter Sullivan, Wayne Law '09, Mary Jo Weindorf, Wayne Law '11, and Avery Rose, Wayne Law ' 13 for research assistance. 
doctrine and similar theories, he urges courts to dismiss actions brought in addition to or in lieu of the remedies Article 5 crafts.

\section{INTRODUCTION}

This paper makes three claims: first, that Article 5 of the Uniform Commercial Code (hereafter "UCC") brings within its remedy section, section 5-111, all contract, tort, and similar causes of action, when the aggrieved party's claim arises out of one or more of the grievances specified in that section ${ }^{1}$ and in the breach of warranty section. ${ }^{2}$ Second, that claims against the beneficiary for "wrongful draws" are covered by the warranty section, section 5-110, and are limited to breach of warranty damages. ${ }^{3}$ Third, that Article 5 forbids application of most other causes of action extrinsic to Article 5, even though the UCC announces that its rules are supplemented by the common law, including the law, among others, of contract, fraud, and misrepresentation. ${ }^{4}$

These three claims rest on the economic loss doctrine, similar theories, and the notion that supplementing UCC remedy provisions with common law claims distorts the general scheme of the various UCC Articles. For simplicity, this paper casts the economic loss doctrine as the chief support for its conclusions.

Part II of this paper explains the causes of action that arise in the letter of credit transaction and that Article 5 contemplates. Part III discusses the economic loss doctrine in order to determine the applicability of the policies it serves in applying the Article 5 remedy and warranty sections. Part IV analyzes the unique nature of letters of credit, the feature of these undertakings that plays a signal role in supporting application of the doctrine in the litigation of these claims. The balance of this paper analyzes the various claims arising out of breach of the duties recognized by Article 5: beneficiary causes of action (Part V), applicant causes of action (Part VI), and issuer and third party causes of action (Part VII).

1. U.C.C. $\$ 5-111$ (2002). The four grievances specified in the remedies section are: [1] beneficiary claims against issuers for wrongful dishonor; [2] applicant claims against beneficiaries for wrongful draw; [3] applicant claims against issuers for wrongful honor; and [4] claims against advisors or nominated persons other than confirmers for breach of an Article 5 obligation. See also U.C.C. $\$ 5-110$ (2002). All UCC references are to the official version of the Uniform Commercial Code. See The Official Text of the 1995 revision of Article 5, §§ 5-101 to 5-118, 2B Part II U.L.A. 136-188 (Master Ed. 2002).

2. U.C.C. $\S 5-110(2002)$.

3. Id.

4. See U.C.C § 1-103(b) (2002). 


\section{THE ARTICLE 5 CAUSES OF ACTION}

The thesis of this paper applies to all letter of credit transactions, simple three-party transactions, multi-party transactions, standby letter of credit transactions, and commercial letter of credit transactions. Because it involves all of the parties, and especially the correspondent bank, the prototypical commercial letter of credit transaction illustrated in the footnote, ${ }^{5}$ serves this paper's discussion best.

In the commercial letter of credit transaction, the buyer of goods applies to its bank to open a letter of credit. ${ }^{6}$ The buyer's bank usually issues the credit electronically through SWIFT $^{7}$ to its foreign correspondent. ${ }^{8}$ The correspondent plays a number of roles. It can simply advise the credit, that is, communicate the terms of the credit to the beneficiary. ${ }^{9}$ It might also confirm the credit. By its confirmation, the

5. John F. Dolan, Commercial Law: Essential Terms and Transactions $§ 5.2$ (2d. ed. Supp. 1997) [hereinafter DOLAN, TERMS AND TRANSACTIONS].

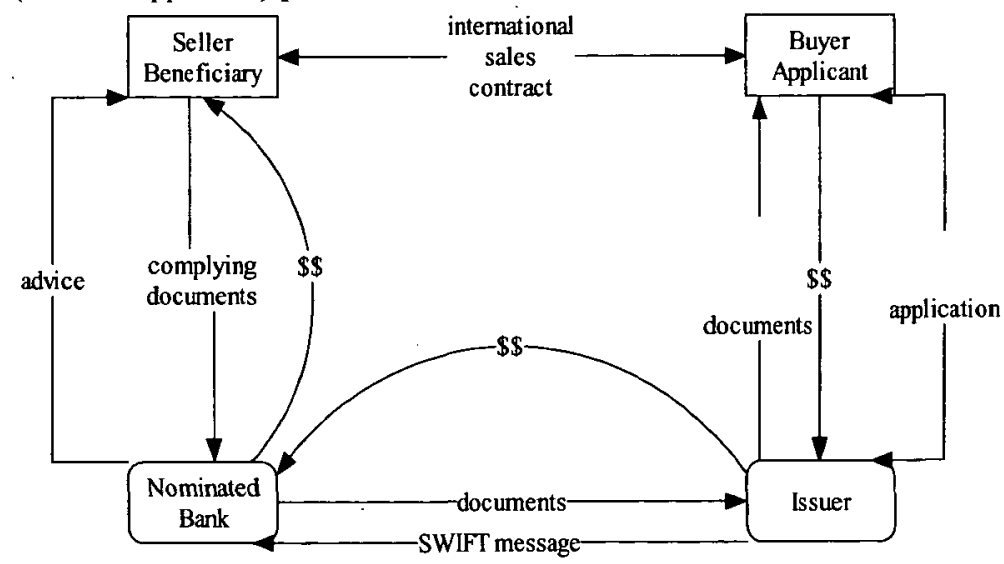

6. The "application" in the illustration is an agreement that governs the relationship between the bank's customer and the bank. Importantly, as further discussion explains, the agreement is a contract, generally subject to contract law remedy rules, but with damages limited under the thesis of this paper. Other relationships in the letter of credit transaction are arguably not contracts but "idiosyncratic form[s] of undertaking." U.C.C. § 5-101 cmt. 1 (2002).

7. SWIFT is the Society for Worldwide Interbank Financial Telecommunication. See SWIFT, www.swift.com (last visited July 30,2012 ).

8. In domestic credit transactions, involving a standby credit, there is, usually, no correspondent. See generally John F. Dolan, Changing Commercial Practices and the Uniform Commercial Code, 26 Loy. L.A. L. Rev. 579, 590 (1993).

9. The advisor's duties are minimal. See U.C.C. $\$$ 5-107(c) (2002), and discussion infra notes $119,123,124,128$. Cf. INT'L CHAMBER OF COMMERCE, UNIFORM CUSTOMS and Practice For Documentary Credits (I.C.C. Pub. No. 600) art. 9(b) (2006) [hereinafter "U.C.P. 600"] (describing the advisor's duties). 
correspondent makes the same undertaking that the issuer makes and is liable as an issuer is liable. ${ }^{10}$

Finally, the correspondent might play one of four roles in honoring the letter of credit, the roles of a nominated bank. In these transactions, the issuer nominates the correspondent (1) to pay the beneficiary's draft ${ }^{11}$ or to pay the beneficiary's demand for payment; ${ }^{12}$ (2) to accept ${ }^{13}$ the beneficiary's time draft, ${ }^{14}$ thereby creating a banker's acceptance; (3) to incur a deferred payment obligation similar to a banker's acceptance but without any negotiable draft; or (4) to negotiate the beneficiary's documents, usually against a draft drawn on the issuer, ${ }^{15}$ rather than a draft drawn on the nominated bank. ${ }^{16}$

Grievances recognized by Article 5 arise in the following circumstances:

(1) advisor mistake

The advisor misadvises the terms of the credit, and the beneficiary suffers loss. ${ }^{17}$

(2) wrongful dishonor

10. See U.C.C. $§ 5-107$ (a) (2002); cf. U.C.P. 600 art. 8 (describing confirmer's undertaking).

11. A draft is an order to pay money, customarily negotiable in form. See U.C.C. § 3104(e) (2002). Under a payment credit, the draft is payable at sight, that is, on demand. For an illustration of a sight draft, see DOLAN, TERMS \& TRANSACTIONS, supra note 5, at document 4-2.

12. Unless the credit requires one or the other, a demand for payment may be negotiable or non-negotiable. See, e.g., First State Bank v. Shuford Mills, Inc., 716 S.W.2d 649, 651 (Tex. Ct. App. 1986); cf. Chase Manhattan Bank v. Equibank, 394 F. Supp. 352 (W.D. Pa. 1975), vacated, 550 F.2d 882 (3d Cir. 1971) (holding "please remit" sufficient demand).

13. "Accept" as it is used here is a term of art. The party that accepts is an acceptor. See U.C.C. \& 3-103(a)(1) (2002). A draft that is accepted becomes an "acceptance." See U.C.C. $\S 3-409$ (a) (2002).

14. A time draft, sometimes called a "usance" draft, is payable some fixed period of time after a certain date or at some specified future date. Typically, a time draft is payable a certain number of days after sight. For an illustration of a time draft, see Dolan, TERMS \& TRANSACTIONS, supra note 5 , at document $4-2$.

15. U.C.P. 600 art. 2(c) (defining "negotiation").

16. These four forms of honoring a letter of credit are explained in UCP 600 arts. 7 \& 8. Most letters of credit incorporate the UCP. This paper assumes that UCC Article 5 governs the remedies available to the parties to the letter of credit transaction. Although most letters of credit incorporate the Uniform Customs, with exceptions not relevant to this paper, Article 5 stipulates that in the event of conflict between Article 5 and the UCP, the UCP governs. See U.C.C. § 5-103 cmt. 2 (2002). On the remedy issues, however, the UCP and Article 5 are not in conflict. The UCP does not fashion remedies. Rather, Article 5 does. See U.C.C. $\$ \S 5-110,5-111$ (2002).

17. U.C.C. $\S 5-111(2002)$. 
The issuer, the nominated bank, or the confirmer dishonors without justification, and the beneficiary or the applicant suffers loss. ${ }^{18}$

(3) wrongful honor

The issuer, the nominated bank, or the confirmer honors when it should have dishonored, and the wrongful honor damages the applicant. ${ }^{19}$

(4) breach of warranty

The beneficiary obtains payment under the credit

(a) by presenting documents to the issuer, the nominated bank or the confirmer that are materially fraudulent or forged, or

(b) when such payment constitutes a breach of the underlying contract that the credit serves, in the illustration, the international sales contract. ${ }^{20}$

In addition, Article 5 alludes to two causes of action but obviously defers to other law that governs them. Those causes arise when:

(5) post honor default default. $^{2}$

Obligors on bankers' acceptances or deferred payment obligations

(6) improvidently granted injunctions

Obligees on bonds issued under UCC $\S 5-109(b)(2)$ suffer loss when applicants or others obtain injunctive relief improvidently. ${ }^{22}$

It helps the analysis to examine these failures in the letter of credit transaction under three headings:

(1) beneficiary claims;

(2) applicant claims; and

(3) issuer and third-party claims.

Yet, before this paper embarks on that analysis, it is necessary to discuss the contours of and policy reason for the economic loss doctrine. That discussion yields a doctrine with somewhat ragged contours and fractured policy footings, yet the investigation supports application of the doctrine in Article 5 litigation.

18. Id.

19. U.C.C. $\S 5-515 \mathrm{cmt} .2$ (2002).

20. U.C.C. $\$ 5-110(2002)$.

21. U.C.C. $\$ 5-108 \mathrm{cmt} .4$ (2002).

22. U.C.C. $\S 5-109$ (b)(2) (2002). 


\section{THE ECONOMIC LOSS DOCTRINE AND SIMILAR DOCTRINES}

\section{A. In Sale of Goods Transactions}

The notion that the economic loss doctrine applies to all economic losses is misleading. Under the doctrine, some losses that are truly economic, as opposed to those that result from tortious behavior, are recoverable; some are not. ${ }^{23}$ Professor Nimmer refers to the doctrine as the "so-called 'economic loss doctrine." 24 In its major sale-of-goods role, the doctrine prevents an aggrieved party from asserting claims in tort for damage to property that the aggrieved party purchased from the defendant. ${ }^{25}$ In some cases, the aggrieved party may use tort theories to recover damage to "other property," that is, property other than that purchased, and to recover damage to persons. ${ }^{26}$ Neither of those claims, damage to "other property" or damage to persons, are economic under the doctrine, even though such losses are in fact, if not under the doctrine's misuse of the term, economic.

23. See, e.g., Stanton v. Bayliner Marine Corp., 866 P.2d 15, 18 (Wash. 1993) (defining "economic loss" for purposes of the doctrine as "the cost of replacing and repairing the yachts"); see also Sacramento Reg'l Transit Dist. v. Grumman, 204 Cal. Rptr. 2d 736, 738-39 (Cal. Ct. App. 1984) (allowing recovery for economic damage to the product itself but denying economic losses such as lost profits). The Restatement (Third) of Torts limits economic losses that are recoverable in tort to losses as a result of harm caused to the "[a] the plaintiff's person; or [b] the person of another when harm to the other interferes with an interest of the plaintiff protected by tort law; or [c] the plaintiff's property other than the defective product itself." RESTATEMENT (THIRD) OF TORTS: PRODS. LIABILITY $\$ 21$ (1998). For an article parsing the various kinds of losses that are recoverable or not recoverable under the doctrine and citing the cases that disclose the inconsistent treatment of the doctrine by the various states, see Ralph Anzivino, The Economic Loss Doctrine: Distinguishing Economic Loss from NonEconomic Loss, 91 MARQ. L. REV. 1081 (2008).

24. Raymond Nimmer, Images and Contract Law-What Law Applies to Transactions in Information, 36 Hous. L. REV. 1, 49 (1999).

25. See, e.g., Isla Nena Servs., Inc. v. Cessna Aircraft Co., 449 F.3d 85 (1 st Cir. 2006) (applying Puerto Rican law); Lockheed Martin Corp. v. RFI Supply, Inc., 440 F.3d 549, 552 (1st Cir. 2006) (applying New Hampshire law); HDM Flugservice GMBH v. Parker Hannifin Corp., 332 F.3d 1025 (6th Cir. 2003) (applying Ohio law); Moorman Mfg. Co. v. Nat'l Tank Co., 435 N.E.2d 443 (Ill. 1982); Stanton, 866 P.2d at 18. Professor Dobbs calls this rule the "stand-alone economic loss" rule. Dan Dobbs, An Introduction to NonStatutory Economic Loss Claims, 48 ARIZ. L. ReV. 713, 725 (2006). Professor Anzivino distinguishes damage to goods sold (economic losses) from damage to other goods (noneconomic losses), the former being subject to contract remedies, the latter to tort remedies. See generally Anzivino, supra note 23.

26. See generally Anzivino, supra note 23. For cases rejecting this distinction, see, e.g., Neibarger v. Universal Coops., 486 N.W.2d 612, 620 (Mich. 1992); Detroit Edison Co. v. NABCO, Inc., 35 F.3d 236, 242 (6th Cir. 1994) (following Neibarger). 
The doctrine has found ready application in the sale of goods setting, where courts will deny tort recovery for losses to the "product," the item purchased by the aggrieved party. ${ }^{27}$ Those same courts hold generally, however, that losses to other property and to persons occasioned by the "product's" defects are recoverable in tort. ${ }^{28}$ The purchaser of a defective grain storage tank cannot use tort causes of action to recover the cost of repairing the tank. The tank is the property, not other property, and the buyer's only remedy is in contract. ${ }^{29}$

Not all jurisdictions delimit the doctrine with this distinction between the "property" purchased and other property and personal injury. Purchasers of equipment to milk dairy cows that was itself defective, injured the cows, and caused lost profits could not resort to tort causes of action because

Generally speaking, tort principles, such as negligence, are better suited for resolving claims involving unanticipated physical injury, particularly those arising out of an accident. Contract principles, on the other hand, are generally more appropriate for determining claims for consequential damage that the parties have, or could have, addressed in their agreement. ${ }^{30}$

The justification for the doctrine in the sale of goods setting rests on the notion that, at the least, in the business-to-business transaction, buyers and sellers can negotiate warranty terms that reflect their perceptions of efficiencies. ${ }^{31}$ Thus, some courts have said contract law is better suited to deal with allocation of risk of damage to the goods sold.

27. See, e.g., Werwinski v. Ford Motor Co., 286 F.3d 661 (3d. Cir. 2002).

28. See, e.g., Saratoga Fishing Co. v. J.M. Martinac \& Co., 520 U.S. 875 (1997); Schiavone Constr., Inc. v. Elgoos Mayo Corp., 436 N.E.2d 1322 (N.Y. 1982); Moorman Mfg. Co., 435 N.E.2d 443.

29. See Moorman Mfg. Co., 435 N.E.2d 443 (emphasis added). Cf. Thiele v. Oddy's Auto \& Marine, Inc., 906 F. Supp. 158 (W.D.N.Y. 1995) (making similar distinction but holding seller liable).

30. Neibarger, 486 N.W.2d at 612 (citations omitted). Cf. Wash. Water Power Co. v. Graybar Elec. Co., 774 P.2d 1199 (Wash. 1989), modified by Wash. Water Power Co. v. Graybar Elec. Co., 779 P.2d 697 (Wash. 1989) (distinguishing economic losses more properly covered by tort law's safety concerns than by contract law's bargain concerns). Washington Water Power invokes Washington's "risk of harm analysis" in applying the economic loss doctrine. Reyton Cedar Knoll, LLC v. HPG Int'l Inc., 289 F. App. 547 (3d Cir. 2008) (applying doctrine to cost of repairing defective roof and consequential damage to interior of building). See also Staton Hills Winery Co. v. Collons, 980 P.2d 784 (Wash. Ct. App. 1999) (doctrine prevents recovery for damage to tank defendant sold to plaintiff and to tank's contents).

31. Saratoga Fishing Co., 520 U.S. at 879-80. 
However, that argument does not, in the view of some, justify denial of tort claims for losses to other property or to persons, damages that tort law, especially product liability law, handles better. ${ }^{32}$

In the commercial setting, the explanation is convincing. ${ }^{33}$ Commercial buyers are in the best position to know whether they want to pay for a warranty, and commercial sellers know whether the price they charge for goods covers the warranty that the buyer seeks. ${ }^{34}$ Presumably, a commercial buyer is in a better position than a commercial seller to know whether the buyer should spend time and money on quality assurance that goods it receives from the seller meet the buyer's product tolerances, whether the buyer is better served by relying on the seller's general quality assurance program, or whether the buyer should pay the seller for additional quality testing.

It is worth mentioning that the varying effects of statutes of limitations often play a critical role in economic loss doctrine cases. Because UCC Article 2 generally allows parties to agree to a one-year statute $^{35}$ that begins to run on delivery of the goods, ${ }^{36}$ and tort statutes generally begin to run only after the aggrieved party learns of or should learn of the defect ${ }^{37}$ plaintiffs who cannot meet the Article 2 statute have no recovery if the economic loss doctrine applies. ${ }^{38}$ In addition, tort

32. For an early case accepting this distinction, see Seely v. White Motor Co., 403 P.2d 145, 151 (Cal. 1965) (en banc). For a more recent and typical case, see Travelers Indem. Co. v. Damman \& Co., 594 F.3d 238 (3d Cir. 2010) (rejecting product liability cross claim when losses were economic only).

33. The Supreme Court in E. River S.S. Corp. v. Transamerica Delaval Inc., 476 U.S. 858 (1986) noted that "a commercial situation generally does not involve large disparities in bargaining power." Id. at 873. In Werwinski, the court applied the doctrine against a consumer purchaser, declining to "engag[e] in a case-by-case, fact intensive inquir[y] to determine [a commercial or a consumer] plaintiff's level of sophistication." Werwinski, 286 F.3d at 663 .

34. For a strong argument supporting that point and making the further point that not all buyers should be saddled with those costs when only a small number of buyers will benefit from the warranty, see George Priest, $A$ Theory of Consumer Product Warranty, 90 YALE L.J. 1297, 1299 (1981).

35. See U.C.C. $\S 2-725(1)(2002)$.

36. See U.C.C. \& 2-725(2).

37. See, e.g., Platt Elec. Supply, Inc. v. EOFF Elec., Inc., 522 F.3d 1049 (9th Cir. 2008). See generally RESTATEMENT (SECOND) TORTS $\S 899 \mathrm{cmt}$. (e) (1979).

38. See AKA Distrib. Co. v. Whirlpool Corp., 137 F.3d 1083, 1085, 1087 (8th Cir. 1998) (holding that contract claim was time-barred by Article 2 four-year statute of limitations and fraud claim was barred by economic loss doctrine); Neibarger, 486 N.W.2d at 623 (holding that plaintiff's claims were governed by UCC and therefore timebarred); Dockhorn v. Kitchens By Kleweno, 71 UCC Rep. Serv. (West) 332 (D. Kan. 2010) (holding that injuries to other property were governed by the two-year tort statute of limitations, not the UCC four-year statute, but that the action was timely brought). 
causes of action allow recovery of consequential damages ${ }^{39}$ and may allow recovery of punitive damages. ${ }^{40}$ Under UCC Article 2, limitations on consequential damages in sales contracts are generally allowed and, understandably, are often adopted by merchant sellers. ${ }^{41}$ Article 5 generally disallows consequential and punitive damages against letter of credit issuers, most often, financial institutions. ${ }^{42}$

Application of the economic loss doctrine is not limited to sales transactions subject to the UCC. Courts applying federal admiralty law have resorted to the doctrine and been instrumental in fashioning its contours. ${ }^{43}$ The principles of the doctrine, moreover, sometimes find application under other rubrics, such as the "gist of the case or gist of the action doctrine" ${ }^{44}$ or the "East River doctrine."

Even if the UCC's four-year statute applies, it may bar warranty actions that are not barred under tort law's statute. See, e.g., Staton Hills Winery Co., 980 P.2d at 784.

39. See, e.g., RESTATEMENT (SECOND) TORTS $§ 917$ (1979) ("One who tortiously harms the person or property of another is subject to liability for damages for the consequences of the harm ....").

40. $I d . \$ 901(\mathrm{c}) \mathrm{cmt}$. $\mathrm{c}$.

41. The statute of limitations under UCC Article 2 is four years, but the parties may reduce the limitation period to one year, but not less. See U.C.C. § 2-725(1) (2003). The rule under the amendments to the official version of UCC Article 2 is similar, but with an exception for transactions involving sales to consumers. The exception does not permit any reduction in the limitation period for such sales. That version of Article 2 has not been adopted by any jurisdiction, however. See UNIFORM LAW COMMISSION, UCC ARTICLES 2 AND 2A (2003), Legislative Report by Act, http://www.uniformlaws.org/Shared/LegReports/LegRpt_Act.pdf (last visited July 30, 2012). Article 2 also permits sellers to disclaim liability for consequential damages and to limit damages to replacement and repair of product defects. See U.C.C. § 2-719(3) (2002). This last limitation on consequential damages is unavailable to a seller that seeks to disclaim consequential damages for personal injuries from defects in consumer goods. Id. For an illustration of that practice, see Dakota Gasification Co. v. Pascoe Bldg. Sys., 91 F.3d 1094, 1096 (8th Cir. 1996).

42. See U.C.C. § 5-111(a), (b), \& (c) (2002).

43. See infra text accompanying note 45.

44. The "gist of the action" doctrine holds that "contract actions arise from breach of duties mutually agreed to, while torts have their basis in violations of duties imposed as a matter of social policy." Sunquest Info. Sys., Inc. v. Dean Witter Reynolds, Inc., 40 F. Supp. 2d 644, 651 (W.D. Pa. 1999) (citations omitted). Under the doctrine, the aggrieved party may sue in tort only if the tort claims are collateral to the contract action. See, e.g., Sun Apparel Warehouse, Inc. v. Nike, Inc. (In re Sun Apparel Warehouse, Inc.), No. 0137760DWS 2003 Bankr. LEXIS 511, at *19 (Bankr. E.D. Pa. May 22, 2003) (describing Pennsylvania's gist of the action doctrine: "[A] party cannot simply recast an ordinary breach of contract claim into a tort claim and in so doing, create a separate and distinct cause of action."). Cf. Little Souls, Inc. v. State Auto Mut. Ins. Co., No. 03-5722 2004 U.S. Dist. LEXIS 4569 , at *5 (E.D. Pa. Mar. 15, 2004) (holding by way of dictum that "when a plaintiff alleges that the defendant committed a tort in the course of carrying out a contractual agreement ... a tort claim is maintainable only if the contract is 'collateral' to conduct that is primarily tortious."). 
gist of the action doctrine distinguishes breach of duties arising out of a contractual relationship from torts arising from actions extrinsic to the contract. The former breaches cannot support tort claims, while the latter may. ${ }^{46}$ The Supreme Court in East River, applying federal admiralty law, used economic loss theory to limit the liability of the seller of goods. ${ }^{47}$

Sale of goods transactions are easy candidates for these doctrines. Widespread litigation is far from a free good, and a cause of action is a problematic asset. When the manufacturer of pressure gear for the bicycle industry receives orders from the National Space Administration, quality assurance by NASA is a superior allocation of costs and yields social savings that would be lost if the law unthinkingly imposed quality assurance costs on the manufacturer. In this setting, caveat emptor makes economic sense, while in other settings, it may not. ${ }^{48}$

\section{B. In Non-Sale of Goods Transactions}

Court application of these doctrines to service contracts where Article 2 warranty bargaining theory does not apply is uneven. Many courts are willing to invoke the doctrine in settings where warranty theory is weak. ${ }^{49}$ Warranty theory is not alone in serving as justification for the economic loss limitations in the sale of goods setting. Some courts justify the doctrine in that setting simply for the reason that the

45. The Supreme Court fashioned an economic loss rule in admiralty in E. River S.S. Corp., 476 U.S. 858. For cases invoking the doctrine of that case, see, e.g., Turbomeca, S.A. v. Era Helicopters LLC, 536 F.3d 351, 354 (5th Cir. 2008); Brown v. Eurocopter S.A., 143 F. Supp. 2d 781, 783 (S.D. Tex. 2001); Hartford Fire Ins. Co. v. Huls Am., 893 F. Supp. 465, 468 (E.D. Pa. 1995).

46. See, e.g., Little Souls, Inc., 2004 U.S. Dist. LEXIS 4569, at *5; In re Sun Apparel Warehouse, Inc., 2003 Bankr. LEXIS at*18-19.

47. E. River S.S. Corp., 476 U.S. at 874.

48. "[T] on warranties to protect themselves against deceptive practices, and if they don't, caveat emptor, which is Latin for "Lump it." Jean Braucher, Deception, Economic Loss and Mass-Market Customers: Consumer Protection Statutes as Persuasive Authority in the Common Law of Fraud, 48 ARIZ. L. REv. 829, 833 (2006). But cf. Moin Yahya, Can I Sue Without Being Injured?: Why the Benefit of the Bargain Theory for Product Liability is Bad Law and Bad Economics, 3 GEo. J.L. \& PuB. PoL'Y 83, 103 (2005) (arguing that even in the consumer sale setting, contract law, not tort theory, should govern claims that do not involve personal injuries).

49. See, e.g., Am. United Logistics, Inc. \& Cent. Am. Warehouse Co. v. Catellus Dev. Corp., 319 F.3d 921 (7th Cir. 2003); Apollo Grp., Inc. v. Avnet, Inc., 58 F.3d 477 (9th Cir. 1995); Emp'rs Ins. of Wausau v. Suwannee River Spa Lines, Inc., 866 F.2d 752 (5th Cir. 1989); Sundance Cruises Corp. v. Am. Bureau of Shipping, 799 F. Supp. 363 (S.D. N.Y. 1992); Ins. Co. of N. Am. v. Cease Elec., Inc., 688 N.W.2d 462, 466-67 (Wis. 2004) (refusing to invoke economic loss doctrine in sale that court characterized as one for services). 
legislature has fashioned the duties of banks under UCC Articles and that the common law of tort should not upset it. ${ }^{50}$ This justification rests on

50. To alter the liability scheme adopted by Article 5 "would disrupt the letter of credit transaction as structured by [Article 5] and would hinder the commercial viability of the letter of credit." Auto Servicio San Ignacio, S.L.R. v. Compania Anonima Venezolana de Navegacion, 765 F.2d 1306, 1308 (5th Cir. 1985) (quoting and affirming district court in stating, "In large part then in adapting letter of credit principles to varying situations in a way that encourages the use of letters of credit is the approved task under Article 5; adapting tort principles not expressly adopted and that tend to discourage the use of such devices is not."); Instituto Nacional de Comercialization Agricola (Indeca) v. Cont'l Ill. Nat. Bank, 858 F.2d 1264, 1269 (7th Cir. 1988) (commenting on the theoretical basis for interpreting and applying Article 5 and refusing to apply tort law). Accord, Confeccoes Texteis de Vouzela, LDA v. Riggs Nat'l Bank of Wash. D.C., 994 F.2d 851 (D.C. Cir. 1993); Krause v. Stroh Brewery Co., 240 F. Supp. 2d 632 (E.D. Mich. 2002). Cf. Fischer \& Mandell, LLP v. Citibank, N.A., 632 F.3d 793 (2d Cir. 2011) (ruling that UCC Article 4 precludes common law claims but permits parties to alter the article's liability scheme by agreement); Advanced Dental Care, Inc. v. SunTrust Bank, 816 F. Supp. 2d 268 (D. Md. 2011) (holding that UCC \& 3-420 preempts negligence claim); Int'l Trade Relationship \& Export v. Citibank, N.A., No. 98 Civ. 8569, 2000 WL 343899 (S.D.N.Y. Mar. 31, 2000) (applying similar reasoning in UCC litigation); Great Lakes Higher Educ. Corp. v. Austin Bank, 837 F. Supp. 892 (N.D. Ill. 1993) (denying recovery in tort in part because UCC Article 3 fashions scheme for allocating liabilities among banks and in part because economic loss doctrine would deny recovery); Pertierra v. Bank of Am., 66 U.C.C. Rep. Serv. 2d (West) 577 (Cal. Ct. App. 2008) (unpublished opinion) (holding that UCC pre-empts negligence claim against bank); Mandolfo v. Mandolfo, 796 N.W.2d 603 (Neb. 2011) (holding that Article 3 displaces claims for negligence by bank in allowing thief to deposit claimant's checks to thief's account, and applying UCC statute of limitations rather that tort statute); Promissor, Inc. v. Branch Bank \& Trust Co., No. 1:08-CV-1704-BBM, 2008 U.S. Dist. LEXIS 98472, at *7 (N.D. Ga. Oct. 31, 2008) (citing Crosson v. Lancaste, 427 S.E.2d 864, 866 (Ga. Ct. App. 1993)) (disallowing negligence claim against bank when claim would "thwart the purposes of the Code"); Texas Stadium Corp. v. Sav. of Am., 933 S.W.2d 616, 622 (Tex. Ct. App. 1996) (Article 3 precluding claims for negligence, conversion, and money had and received). See also Ma v. Merrill Lynch, Pierce, Fenner \& Smith, Inc., 597 F.3d 84 (2d Cir. 2010) (holding that UCC $\S 4 A-505$ barred common law claims for allegedly unauthorized wire transfers); Crawford v. JP Morgan Chase Bank, N.A., 70 UCC Rep. Serv. 2d (West) 96, at *5 (E.D. Mich. 2009) (Article 3 statute of limitations preempting causes of action for breach of contract, promissory estoppel, and unjust enrichment); Rector v. Harlstad Farmers Elev., 66 UCC Rep. Serv. 2d (West) 777 (Minn. Ct. App. 2008) (Article 2 breach of warranty rules preempt common law cause of action for breach of contract); but cf. Ross v. Bank of Am., N.A., 693 F. Supp. 2d 692 (S.D. Tex. 2010) (holding that UCC Article 3 does not displace cause of action for money had and received); EPCO Carbonoxide Prods., Inc. v. Bank One, B.A., No. 04-2324, 2007 U.S. Dist. LEXIS 33719 (W.D. La. May 8, 2007) (refusing to invoke economic loss doctrine to bar claim for breach of contract to issue letter of credit); Bucci v. Wachovia Bank, N.A., 591 F. Supp. 2d 773 (E.D. Pa. 2008) (holding that UCC $\$ 4-406$ does not preclude negligence and breach of contract counts against drawee bank); Busy Bec, Inc. v. Wachovia Bank, No. 97CV5078, 2006 Pa. Dts. \& Cnty. Dec. LEXIS 238, at *60 (Feb. 28,2006 ) (refusing to apply gist of the action doctrine to breach of contract and tort 
the idea that the legislature has fashioned the parties' remedies and that the remedies are exclusive. ${ }^{51}$

It may not suffice, however, to infer a limitation against tort recovery from a statutory provision for remedies. Unless the legislative regime is expressly preemptive or unless invoking torts rather clearly disturbs the legislative scheme, courts may go too far when they inhibit tort recovery in non-sale settings. When the legislative scheme serves a clear policy of limiting recovery, some courts feel justified in invoking the doctrine. ${ }^{52}$

In non-sale cases, moreover, courts and commentators look for some kind of relationship between the parties that justifies application of liability for negligence. Professor Nimmer's conclusions regarding liability for negligent representation are instructive. He concludes that most courts will enforce tort liability for negligent misrepresentation "only if there is a special relationship with the provider in which the information is intended to influence the recipient's acts." 53 One indication of such intimacy lies in notions of privity, which, as one court has observed, "is not a wholly artificial concept." 54

actions against issuer for wrongful dishonor). For criticism of the Busy Bee case, see 1 Dolan Treatise at 7 7.07 (2011 Cum. Supp. No. 2).

51. See, e.g., SMI Owen Steel Co. v. Marsh USA Inc., 520 F.3d 432, 443 (5th Cir. 2008) (refusing to apply economic loss doctrine to prohibit tort action against insurance broker that failed to fulfill statutorily created duty); Banco del Estado v. Navistar Int'l Transp. Corp., 954 F. Supp. 1275 (N.D. Ill. 1997) (permitting issuer to claim against beneficiary of a letter of credit in fraud and rejecting beneficiary's claim that warranty section in pre-revised Article 5 provided sole remedy for fraud). In the interest of candor, this author must admit that in his treatise, he approved the court's ruling in Banco del Estado, an approval that in retrospect he now regards as ill-advised. See 1 DolaN TREATISE, supra note 50, at 9-85.

52. Some courts resort to the Code's policy provision, Section 1-103, to delimit the use of tort theories to supplement the UCC. See, e.g., Ross v. Bank of Am., N.A., 693 F. Supp. 2d 693 (holding that UCC $\$ 3-420$ does not displace but limits use of money had and received cause of action and, therefore, that UCC $\S 1-103$ allows cause of action). That section articulates the Code policy of supplementing Code provisions with common law principles, "[u]nless displaced by the particular provisions of" the Code. U.C.C. $\S 1-$ 103 (2002).

53. Nimmer, supra note 24, at 52.

54. Evra Corp. v. Swiss Bank Corp., 673 F.2d 951, 956 (7th Cir.), cert. denied, $459^{\circ}$ U.S. 1017 (1982). Actions by letter of credit applicants against confirmers or nominated banks and claims by confirmers and nominated banks against applicants are prime candidates for application of that doctrine if the claims rest on contract law. Yet, the scope of privity is narrow. Its protection against claims does not reach tort claims, the claims this paper argues should not arise in most letter of credit litigation. For authority suggesting that the absence of privity in product liability cases prevents application of the economic loss doctrine, see Indemnity Ins. Co. of N. Am. v. Am. Aviation, Inc., 399 F.3d 1275,1276 (11th Cir. 2005). Presumably, the absence of privity prevented the aggrieved party from negotiating loss allocation with the defendant. There being no such opportunity, the economic loss doctrine does not apply. 


\section{Exceptions for Intentional Torts}

Before examining the applicability of the economic loss doctrine to UCC Article 5, it is helpful to examine important limits some courts have fashioned for it. These limits arise out of the breaching party's bad faith, fraud or intentional wrong. While courts apply the doctrine to forbid actions based on negligent performance of duty, ${ }^{55}$ negligent misrepresentation, ${ }^{56}$ and product or strict liability, ${ }^{57}$ there is authority that actions constituting bad faith such as deceit, intentional misrepresentation or common law fraud, survive application of the doctrine. ${ }^{58}$ It may be that the doctrine should prohibit even those causes of action, though that argument finds little support in the rationales courts have offered for the doctrine, ${ }^{59}$ and the cases are in disarray ${ }^{60}$ As

55. See, e.g., Am. United Logistics, Inc., 319 F.3d at 921; Detroit Edison Co., 35 F.3d at 236; Neibarger, 486 N.W.2d at 612. Cf. Sundance Cruises Corp., 799 F. Supp. at 383 (applying doctrine to prohibit claim for damages resulting from defendant's gross negligence).

56. See e.g., Holden Farms, Inc. v. Hog Slat, Inc., 347 F.3d 1055 (8th Cir. 2003); HDM Flugservice GMBH, 332 F.3d 1025. Contra Level 3 Comm'ns, LLC v. Liebert Corp., 535 F.3d 1146, 1162 (10th Cir. 2008).

57. See, e.g., Thiele, 906 F. Supp. at 158; Va. Surety Co. Inc. v. Am. Eurocopter Corp., 955 F. Supp. 1213 (D. Haw. 1996); Stanton, 866 P.2d at 18.

58. See, e.g., Giles v. Gen. Motors Acceptance Corp., 494 F.3d 865, 876 (9th Cir. 2007); Cerabio LLC v. Phillips Plastics Corp., 410 F.3d 981 (7th Cir. 2005); In re Chicago Flood Litig., 680 N.E.2d 265 (Ill. 1997). Professor Dobbs would not limit such tort claims if the torts are "independent." Arguably, then, fraud in a related transaction would not be subject to the tort, but fraud in the letter of credit transaction itself, say, by the issuer or the beneficiary, would be subject to the doctrine. See Dobbs, supra note 25, at 728. Professor Anzivino notes that some courts have applied the doctrine if the fraud is not "intrinsic to the contract." See Anzivino, supra note 23, at 1096. For authority suggesting a distinction between fraud that is "interwoven" with an undertaking and fraud that is "extraneous" to it, see Christopher J. Farielli, Comment, Wading into the Morass: An Inquiry into the Application of New Jersey's Economic Loss Rule to Fraud Claims, 35 RUTGERS L.J. 717, 730 (2004) (footnote omitted); and for authority that the fraud exception extends to fraud that induces a party to enter into a transaction, see Steven C. Tourek, Thomas H. Boyd, \& Charles J. Schoenwetter, Bucking the "Trend": The Uniform Commercial Code, the Economic Loss Doctrine, and Common Law Causes of Action for Fraud and Misrepresentation, 84 IOWA L. REV. 875 (1999).

59. One court used the doctrine to bar a buyer's claim for misrepresentation of product history. The court held that the buyer's decision to rely on the representation was a contractual decision, that is, a decision not to seek warranty or other contract protection and, therefore, that the economic loss doctrine barred the claim. See Rich Prods. Corp. v. Kemutec Inc., 241 F.3d 915, 919 (7th Cir. 2001). See also Cerabio, 410 F.3d 981 (summary judgment on claims for fraud and negligent representation and negligent misrepresentation in breach of contract dispute); Holden Farms, Inc., 347 F.3d at 1062 (economic loss doctrine bars negligent misrepresentation claim in warranty breach setting); Instituto Nacional De Comercializacion Agricola (Indeca) v. Continental Ill. 
we shall see, however, Article 5 suggests that instances of "material" fraud ${ }^{61}$ give rise to breach of warranty claims and that invoking tort law in the event of beneficiary fraud is not necessary. Article 5 limits liability for fraudulent draws, providing protection to issuers and applicants through the warranty section, ${ }^{62}$ and limits the liability of beneficiaries, which are often banks, to actual damages proved. ${ }^{63}$

In the sale of goods setting, one cannot contend that a buyer whose seller has engaged in such intentional misbehavior can properly negotiate warranties. The whole purpose of negotiation is to allocate risks on the basis of honest dealing, which yields efficient allocation of resources. Intentional bad faith, intentional misrepresentation, and common law fraud with its intention feature interfere with proper allocation of resources and should survive application of the economic loss doctrine in the sale of goods setting where courts have invoked warranty theory as the doctrine's predicate.

In situations relying on the presence of a statutory scheme as the predicate, one might move more cautiously in forbidding claims based on these commercially baleful practices. Without clear direction from the statute, the better course is to sustain such claims. There is always the risk, of course, that the trier of fact will misapply the higher proof burdens that the law imposes in these instances, ${ }^{64}$ but weaknesses of the trial system are not the subject of this paper, which assumes, perhaps at the risk of Pollyannaism, that judges and jurors follow the law.

Nat'l Bank \& Trust Co., 675 F. Supp. 1515 (N.D. Ill. 1987), aff'd, 858 F.2d 1264 (7th Cir. 1988) (suit denying claim against letter of credit confirmer for negligent misrepresentation); but cf. Level 3 Comm'ns, $L L C, 535 \mathrm{~F} .3 \mathrm{~d}$ at 1163 (allowing claim for negligent misrepresentation that arose "independently of the [a]greement"). Professor Anzivino complains that the fraud exception to the doctrine is too narrow. See Anzivino, supra note 23. Professor Braucher would disagree. See Braucher, supra note 48.

60. Professors White and Summers summarize the situation: "In some states this now burgeoning common law doctrine has achieved the status of the 'economic loss doctrine,' meaning that once loss is defined as 'economic' it cannot be recovered at least in negligence or strict tort and perhaps not in fraud or misrepresentation." J. WHITE \& R. SUMmERS, UNIFORM COMMERCIAL CODE 539 (6th ed. 2010). For more of the cases and discussion of them, see R. Joseph Barton, Drowning in a Sea of Contract: Application of the Economic Loss Rule to Fraud and Negligent Misrepresentation Claims, 41 WM. \& MARY L. REV. 1789 (2000).

61. U.C.C. $\$ 5-109$ (a) (2002).

62. U.C.C. $\S 5-110(2002)$.

63. U.C.C. $\$ 5-111(2002)$.

64. The burden of proof in fraud cases is usually one of "clear and convincing" evidence. See, e.g., BancOklahoma Mortg. Corp. v. Capital Title Co. Inc., 194 F.3d 1089, 1104 (10th Cir. 1999); D.R.C.D.T., Inc. v. Integrity Ins. Co., 816 F.2d 273, 278 (6th Cir.1987) (holding burden of proof of clear and convincing evidence applicable to every case involving fraud). 
With respect to the bad faith claims, one must take account of the curious nature of that term. Essentially, "good faith" is an excluder, that is, the absence of "bad faith." 65 Generally, the UCC imposes two requirements for good faith: "[1] honesty in fact and [2] observance of reasonable commercial standards of fair dealing.",66 Under the UCC's general definition, then, bad faith is either dishonesty or failure to observe the standards, both of which are rather more easily discernable than honesty and reasonable observance. UCC Article 5, however, departs from the dual feature good faith definition limiting good faith to honesty in fact alone. ${ }^{67}$ Thus, in Article 5, the subject of this paper, the only instance of bad faith is dishonesty.

The distinction obviously narrows the good faith requirement. It also signals legislative concern that reasonableness, the critical ingredient of the second good faith requirement, not be a matter of litigation in Article $5^{68}$-a matter that this paper suggests below informs the scope of the economic loss doctrine's applicability in Article 5.

\section{Conclusions Regarding the Doctrine's Policies}

This summary does little to resolve the numerous conflicts in application of the doctrine to various settings, and little to fashion the doctrine's limits as a general matter. ${ }^{69}$ The summary does show, however, that courts use what Professor Dobbs suggests is pragmatism as a rational approach to application of the doctrine. ${ }^{70} \mathrm{He}$ concludes that "economic harm poses a threat of infinite economic repercussions and that a limit should be imposed by denying the negligence claim where there is real threat of such repercussions." ${ }^{71}$ The language of Article 5

65. The leading article is Robert S. Summers, "Good Faith" in General Contract Law and the Sales Provisions of the Uniform Commercial Code, 54 VA. L. REV. 195, 196, 232-43 (1968).

66. U.C.C. $\S 1-201(\mathrm{~b})(20)(2002)$.

67. U.C.C. $\S 5-102(a)(7)(2002) ; c f$. U.C.C. $\$ 1-201(b)(20)$ (excluding Article 5 from the general "good faith" definition).

68. U.C.C. $\$ 5-102 \mathrm{cmt} .3$ (2002).

69. "[T] Ame American law of liability for purely economic losses is much less well settled and less uniform than one might wish it to be." Herbert Bernstein, Civil Liability for Pure Economic Loss under American Tort Law, 46 AM. J. CoMP. L. 111, 125 (1998).

70. Dobbs, supra note 25 , at 714 .

71. Id. Cf. John Siliciano, Negligent Accounting and the Limits of Instrumental Tort Reform, 86 MICH. L. REV. 1929, 1946 (1988) (dealing with third-party claims for negligence and counting economic loss doctrine as "[a]mong the most important" doctrines fashioned by courts even when losses are foreseeable to deny recovery in virtue of "apprehensive[ness] about the vastly expanded tort liability," Id. at 1934. But, listing exaggerated damages claims, fraudulent claims, and lower standards of care as further 
discloses a clear legislative purpose to spike the threat of infinite economic repercussions. ${ }^{72}$ Application of the doctrine serves that legislative purpose; invocation of tort remedies disserves it. Judge Posner reaches similar conclusions. ${ }^{73}$ In short, persuasive commentary, looking not at Article 5 but at the economic loss doctrine as a general principle, urges restraint of one sort or another against a loose tort regime. Analysis of the economic loss doctrine in Article 5 begins with a search for reasons to limit tort in letter of credit transactions. That search yields results that sometimes cut in favor of limits and, at other times, against them, but reading the statute as a whole favors prohibition of torts in the causes of action this paper addresses.

\section{THE UNIQUE NATURE OF THE LETTER OF CREDIT}

Letters of credit are not negotiable instruments. ${ }^{74}$ Nor are they suretyship undertakings. ${ }^{75}$ Although courts ${ }^{76}$ and Article 5 itself $^{77}$ are sometimes inclined to refer to the letter of credit as a contract, that characterization is also misleading. The letter of credit is an "idiosyncratic form of undertaking." 78 Its nature was for many years the subject of intense debate among Commonwealth nation scholars, who seem to have given up on determining what letters of credit are. ${ }^{79}$ Some

concerns). See also Gary T. Schwartz, Economic Loss in American Tort Law: The Examples of J'Aire and of Products Liability, 23 SAN Diego L. ReV. 37 (1986).

72. See U.C.C. \$ 5-111 (2002).

73. See Richard A. Posner, Common-Law Economic Torts: An Economic and Legal Analysis, 48 ARIz. L. REV. 735, 736-39 (2006) (concluding that courts should approach claims pragmatically, entertaining the claims in some cases, dismissing them in others, with the purpose in all cases of serving three economic policies underpinning the economic loss doctrine: rejecting claims (1) when the loss is personal rather than social; (2) when it is difficult for the defendant to estimate potential losses; and (3) when it is difficult "to delimit the victims").

74. First, they are not instruments as the UCC defines that term. See U.C.C. § 3104(b) (2002). Moreover, they do not satisfy the formal requisites for negotiability. See U.C.C. $\S 3-104(a)$.

75. See U.C.C. § 5-102 cmt. 6 (2002); U.C.C. § 5-103 cmt. 1.

76. See, e.g., Exxon Co. v. Banque de Paris et des Pays-Bas, 889 F.2d 674, 678 (5th Cir. 1989); Kerr Constr. Co. v. Plains Nat'l Bank, 753 S.W.2d 181 (Tex. Ct. App. 1987). But cf. Montgomery Ward, LLC v. Wiseknit Factory, Ltd. (In re Montgomery Ward, LLC), 292 B.R. 49, $54-55$ (Bankr. D. Del. 2003) (tiring of the practice of treating letters of credit as contracts, the court observed: "[ $t$ ]he unwashed characterize the letter of credit as a contract between the beneficiary and the issuer ...").

77. For a UCC official comment using similar locution, see U.C.C. $\$ 5-114 \mathrm{cmt} .1$ (2002).

78. U.C.C. $\$ 5-101 \mathrm{cmt} .(2002)$.

79. Ali MALEK QC \& DAVID Quest, JACK: Documentary Credits $\$ 5.1$ (4th ed. 2009) (the leading U.K. treatise characterizing letter of credit as "binding contract"). 
pre-code scholars treated the letter of credit as a "commercial specialty" akin to a sealed instrument. ${ }^{80}$

We know, however, that letters of credit need no consideration to be binding. ${ }^{81}$ They come into existence without the parties' observance of the offer-and-acceptance paradigm of contract formation, ${ }^{82}$ and must be in the form of a "record." 83 Letters of credit may not be issued by individuals for "personal, family, or household purposes," irrevocable even though silent on revocability and even though there is no reliance on them. ${ }^{85}$ Finally, they can give rise to an important and strict estoppel against their issuers, that is, a preclusion that arises without any showing of detriment or reliance. ${ }^{86}$ Letters of credit, moreover, are generally subject to the formalism that contract law has eschewed. They terminate on their stated expiry without regard to any beneficiary excuse for tardiness ${ }^{87}$ and are generally subject to the perfecttender rule that contract law long ago jettisoned. ${ }^{88}$ Most of the time, letters of credit are subject to international rules formulated especially for them by a trade association, the International Chamber of Commerce. ${ }^{89}$ A subset of them, the standby letter of credit, is the subject of a United Nations Convention. ${ }^{90}$ When banks, which issue most letters of credit,

Clive Schmitthoff took a different view at an earlier time, referring to the letter of credit as "an institution sui generis." Clive M. Schmitthoff, The Transferable Credit, $1988 \mathrm{~J}$. Bus. L. 49, 51 (1988).

80. See Morton C. Campbell, Guaranties and the Suretyship Phases of Letters of Credit, 85 U. PA. L. REv. 175, 261 (1936-37); Rufus J. Trimble, The Law Merchant and the Letter of Credit, 61 HARV. L. REV. 981 (1948); Omar F. Hershey, Letters of Credit, 32 HARV. L. REV. 1 (1918).

81. U.C.C. $\$ 5-105$ (2002). This is not a new rule. It codifies the eighteenth century holding of Lord Mansfield in Pillans v. Van Mierop, (1765) 97 Eng. Rep. 1035 (K.B.); 3 Burr. 1663. See U.C.C. $\S 5-105 \mathrm{cmt}$. For the view that Lord Mansfield's ruling was the "conspicuous failure of a great judge," see William E. McCurdy, Commercial Letters of Credit, 35 HaRv. L. Rev. 539, 565 (1922).

82. U.C.C. § 5-106(a) (2002).

83. U.C.C. § 5-104 (2002).

84. U.C.C. $\S 5-102(a)(9)(2002)$.

85. U.C.C. \& 5-106(a) (2002).

86. See U.C.C. $\S 5-108$ (c) (2002); Int'l Chamber of Commerce, Uniform Customs and Practice for Documenting Credits, I.C.C. Pub. No. 600 art. 16(f) (2006).

87. See, e.g., K.G. Cornwall, LLC v. Beazer Homes Corp., No. 07 Civ. 2881, 2008 U.S. Dist. LEXIS 15909 (S.D.N.Y. Feb. 28, 2008); Todi Exports v. Amrav Sportswear, Inc., No. 95 Civ. 6701 (BJS), 1997 WL 61063, at *4 (S.D.N.Y. Feb. 13, 1997).

88. As a general rule, beneficiaries can expect issuers to honor if the beneficiary's presentation "appears on its face strictly to comply with the terms and conditions of the letter of credit." U.C.C. \$ 5-108(a) (2002).

89. See U.C.P. 600 , supra note 9.

90. See 1995-United Nations Convention on Independent Guarantees and Stand-By Letters of Credit, UNCITRAL, 
issue such undertakings, the form of their obligation and their practices are subject to special bank regulations fashioned for letters of credit. ${ }^{91}$

The critical point of all this is that letters of credit are unique commercial devices, not negotiable instruments, not suretyship undertakings, and not contracts. Except to the extent precedent discloses the policies that the economic loss doctrine serves, the decision whether to apply the economic loss doctrine in letter of credit cases rests on the nature of the credit undertaking and not on precedent dealing with contracts or other obligations. As this discussion of the doctrine's history and application discloses, courts have fashioned the doctrine not so much as positive law but rather as a prerogative that permits them to apply it selectively. Whether the nature of letters of credit supports selective application or universal application is the question this paper addresses next.

\section{BENEFICIARY CAUSES OF ACTION}

\section{A. For Wrongful Dishonor}

When the letter of credit issuer dishonors the beneficiary's complying presentation, the beneficiary may face three kinds of loss: (1) loss of the funds that the issuer should have paid; (2) consequential damages; and (3) in commercial letter of credit transactions, incidental expenses incurred salvaging goods that may be in transit or rotting on a dock. $^{92}$ In the commercial letter of credit transaction, however, the beneficiary may be able to recoup all or part of its loss by reselling the goods to a third party. The Article 5 remedy provision addresses in subsection (a) each of those losses and the possibility that the beneficiary might chose to mitigate its damages. ${ }^{93}$ Significantly, section 5-111(a) measures the pecuniary loss by the amount of the beneficiary's draw on the credit without requiring the beneficiary to mitigate. ${ }^{94}$ The disappointed beneficiary, then, may let the goods rot and still recover in

http://www.uncitral.org/uncitral/en/uncitral_texts/payments/1995Convention_guarantees _credit.html (last visited July 30, 2012).

91. For the federal regulation, see Comptroller of the Currency, Dep't of the Treasury., 12 C.F.R. $\S 7.1016$ (2008). For a similar state regulation, see Investments in Commercial, Corporate and Business Loans by Savings Banks and Saving \& Loan Associations; Leasing Transactions; Letters of Credit, 3 N.Y. Comp. COdES R. \& REgS. tit. $3 \S 77.5(2012)$.

92. U.C.C. § 5-111(a) (2002).

93. Id.

94. Id. 
full, plus interest on the unpaid amount. ${ }^{95}$ The beneficiary may also recover incidental damages and attorney's fees, if they are incurred. ${ }^{96}$ The beneficiary may not recover consequential damages, however. ${ }^{97}$

The pattern is instructive. It reveals as the legislature's purposes: (1) by creating a per se damages rule in the amount of the beneficiary's dishonored draft, a policy of creating disincentives for the issuer to dishonor; ${ }^{98}$ and (2) by fashioning the per se damages rule and by prohibiting recovery of consequential damages a policy of fostering certainty in wrongful dishonor litigation. The official comments assert that given the prohibition of consequential damages " $[a]$ fortiori punitive and exemplary damages are excluded." 99 Consequential damages and punitive damages, of course, are notoriously difficult to estimate ex ante. The remedy section mandates attorney's fees, perhaps as a surrogate for punitive damages, but one that is less difficult to estimate. ${ }^{100}$ In short, this complex set of rules reflects the same policy limitations that the economic loss doctrine serves.

Application of tort liability, of course, upsets the certainty feature, opens the damages in a way that renders them impossible for the issuer to estimate, and creates an imbalance in the Article's remedy rules. It also renders problematic banks' compliance with regulations that order banks to issue letters of credit only if their liability is restricted to an

95. See U.C.C. § 5-111(c) (2002). The interest rule supports the legislature's desire to ensure that the law does not create an incentive for the issuer to breach. Courts have held that interest runs from the date of wrongful dishonor until payment. See Data Gen. Corp. v. Citizens Nat'l Bank, 502 F. Supp. 776 (D. Conn. 1980); Décor by Nikkei Int'l, Inc. v. Fed. Republic of Nigeria, 497 F. Supp. 893 (S.D.N.Y. 1980), aff d, 647 F.2d 300 (2d Cir. 1981), cert. denied, 454 U.S. 1148 (1982); cf. U.S. Bank, NA v. BankPlus, No. 09-0784KD-B, 2010 U.S. Dist. LEXIS 33413 (S.D. Ala. Apr. 5, 2010) (computing interest from date of presentment without regard for issuer's unsuccessful effort to interplead the letter of credit proceeds).

96. U.C.C. $\$ 5-111$ (b) (2002).

97. Id.

98. "Because the letter of credit depends upon speed and certainty of payment, it is important that the issuer not be given an incentive to dishonor." U.C.C. $\S 5-111 \mathrm{cmt}$. 1 (2002). Note also that the dishonoring issuer may not subrogate itself to its customer's causes of action. The subrogation rule of Article 5 permits subrogation only if the issuer honors, not if it dishonors. See U.C.C. § 5-117(a) (2002). The remedies section augments that disincentive, furthermore, by stipulating that the court must award attorney's fees to the prevailing beneficiary. See U.C.C. \$ 5-111(e) (2002).

99. U.C.C. § 5-111 cmt. 4 (2002) (second sentence). The comment adds that punitive damages under statutory or common law duties "arising outside of" Article 5 are recoverable. Id.

100. U.C.C. § 5-111(e) (2002). 
amount certain. ${ }^{101}$ The remedies section balances the issuer's protection against speculative consequential and punitive damages on the one hand with the beneficiary's protection against the issuer's claim that the beneficiary should mitigate and the beneficiary's absolute claim for attorney's fees on the other, all in a manner that appears to be mindful of regulator's concerns that financial institutions not be open to unlimited liability.

Claims for negligence, ${ }^{102}$ breach of contract, ${ }^{103}$ negligent misrepresentation, ${ }^{104}$ intentional misrepresentation, ${ }^{105}$ fraud, ${ }^{106}$ conversion, ${ }^{107}$ detrimental reliance, ${ }^{108}$ intentional interference with contractual rights, ${ }^{109}$ unjust enrichment, ${ }^{110}$ conversion, ${ }^{111}$ breach of the implied covenant of good faith, ${ }^{112}$ tortious and reckless conduct, ${ }^{113}$ and breach of fiduciary duty ${ }^{114}$-all of which beneficiaries have pleaded in their suits for wrongful dishonor-upset the legislature's balance and

101. "As a matter of safe and sound banking practice, banks that issue independent undertakings should not be exposed to undue risk. At a minimum, banks should consider the following: . . . . The undertaking should be limited in amount." Comptroller of the Currency, Dep't of the Treasury, 12 C.F.R. $\$ 7.1016$ (b)(1)(ii) (2008).

102. Bath Iron Works Corp. v. WESTLB, No. 02 Civ. 2272 (RCC), 2004 U.S. Dist. LEXIS 6212, at *14 (S.D.N.Y. Apr. 12, 2004); cf. Gen. Cable CEAT, SA v. Futura Trading, Inc., No. 82 Civ. 1087 (RLC), 1983 WL 1156 (S.D.N.Y. Jan. 18, 1983).

103. Exp.-Imp. Bank of the U.S. v. United Cal. Disc. Corp., 738 F. Supp. 2d 1047, 1060 (C.D. Cal. 2010).

104. LaBarge Pipe \& Steel Co. v. First Bank, 550 F.3d 442 (5th Cir. 2008); Indeca, 675 F. Supp. at 1515 (suit against confirmer for recklessness and negligent misrepresentation).

105. Equal Justice Found. v. Deutsche Bank Trust Co. Am., 61 U.C.C. Rep. Serv. 2d (West) 120, No. C2-04-228, 2006 U.S. Dist. LEXIS 69890, at *19-20 (S.D. Ohio Sept. 27, 2006) (anticipatory dishonor case).

106. Creaciones Con Idea, S.A. de C.V. v. Mashreqbank PSC, 51 F. Supp. 2d 423 (S.D.N.Y. 1999); $c f$. Equal Justice Found. v. Deutsche Bank Trust Co. Am., 412 F. Supp. 2d 790 (S.D. Ohio 2005) (anticipatory dishonor case).

107. Contitrade Servs. Corp. v. Eddie Bauer, Inc., 794 F. Supp. 514, 516 (S.D.N.Y. 1992).

108. LaBarge Pipe \& Steel Co., 550 F.3d at 464.

109. Schmueser v. Burkburnett Bank, 937 F.2d 1025 (5th Cir. 1991); Hubbard Bus. Plaza v. Lincoln Liberty Life Ins. Co., 596 F. Supp. 344 (D. Nev. 1984), aff'd, 844 F.2d 792 (9th Cir. 1988) (table).

110. Exp.-Imp. Bank of the U.S., 2010 U.S. Dist. LEXIS 91170 , at *31.

111. RBC Bank (USA) v. Holiday Isle, LLC, No. 09-0038-WS-C, 2009 U.S. Dist. LEXIS 84307 (S.D. Ala. Sept. 14, 2009); Amwest Sur. Ins. Co. v. Concord Bank, 248 F. Supp. 2d 867 (E.D. Mo. 2003)

112. Fanslow v. N. Trust Co., 700 N.E.2d 692 (Ill. App. Ct. 1998).

113. Esso Petroleum Can. v. Sec. Pac. Bank, 710 F. Supp. 275 (D. Or. 1989).

114. Bath Iron Works Corp., 2004 U.S. Dist. LEXIS 6212. 
certainty. Arguably, there is no room for tort in wrongful dishonor cases and courts should dismiss those claims. ${ }^{115}$

\section{B. Wrongful Advice}

The letter of credit industry has taken steps to reduce the incidence of mistake in advices. SWIFT ${ }^{116}$ permits banks to communicate electronically, and most bank advisors send the beneficiary a printed copy of the electronic credit it receives from the opening bank or the electronic copy itself. It is not unusual for the applicant's data entry clerks, using electronic data interchange, to send data to the issuer, whose entry clerks enter it wholesale into the issuer's software and cause the credit to issue to the advisor in electronic format. Finally, SWIFT limits membership and polices its program with various algorithms, software, and other safety devices that render the identity of senders and advisors reliable and virtually error free - a vast improvement over devices the industry used in former times (teletype machines that ran out of paper or bank signature records that required bankers to act as handwriting experts comparing signatures on letters of credit). ${ }^{117}$ An advisor's duty to the beneficiary and to the issuer is to render the advice accurately and to the beneficiary to check the apparent authenticity of the issuer. SWIFT renders the risk of error in either case minimal.

Nonetheless, there can be mistakes. ${ }^{118}$ Yet, mistakes other than those mentioned are not actionable. If, then, an advisor does not advise in timely fashion, so that the beneficiary does not receive the advice in time to draw on it, the advisor is not liable. ${ }^{119}$ One might argue simply that the advisor has no duty to advise in timely fashion or that there is no privity between the advisor and the beneficiary. The more convincing answer to advisor non-liability in this setting and others outside the scope of the duties imposed by Article 5 is that the beneficiary is in the better position to know the consequences of the tardiness or mistake. In the unlikely event that an advisor issues a credit with terms or conditions that vary the terms of the underlying contract, the beneficiary will know of the mistakes, but the advisor, a stranger to that underlying contract will not.

115. As some courts have in fact done. See sources cited supra note 52 .

116. For discussion of SWIFT, see discussion supra note 7.

117. For discussion of the technology evolution in the issuance and enforcement of letters of credit in the banking setting, see 1 Dolan TREATISE, supra note 50, at $\uparrow 1.03$.

118. See AC Monk \& Co. v. UBAF Arab Am. Bank, 875 F. Supp. 311 (E.D.N.C. 1995).

119. These are the facts of Sound of Market Street, Inc. v. Cont'l Bank Int'l, 819 F.2d 384,384 (3d Cir. 1987) (holding that the advisor was not liable to the beneficiary for late delivery of the advice). 
Similarly, if advice is late, the beneficiary can take steps to protect itself. It should not ship goods before it receives the advice. If the advice does not arrive, it must notify the applicant, and ask whether the credit has been issued. If the terms of the advice vary from the terms of the underlying contract, the beneficiary should obtain an amendment before shipping the goods. Manufacturers should not begin the manufacture of specialty goods before they know there is a credit in place on which they can draw. In these cases, the beneficiary knows the critical facts. The advisor does not. To impose liability on the advisor for these mistakes flies in the face of the economic loss doctrine's policies.

The possibility of loss to the beneficiary, moreover, from breach of the advisor's duties under the UCP is unlikely; but losses, if they do arise out of such breach, should fall on the advisor. The advisor can check the apparent authenticity of the request from the issuer or can take steps to ensure that it transmits the advice accurately. The beneficiary, however, is in the superior position to know facts and to guard against other mistakes.

Article 5 does not address the issue of damages in the event of advisor breach. ${ }^{120}$ The certainty concerns are evident in the issuer liability rules for wrongful dishonor come into play here. Arguably, it is more consistent with the policy evident in the remedy section and with the economic loss doctrine to make the advisor liable for the full amount of the beneficiary's loss when the issuer dishonors because of the advisor's mistake. One could use contract damages rules by analogy and force the beneficiary to prove its losses by a preponderance of the evidence. That approach guarantees litigation with its attendant costs to both parties. A per se rule similar to that of section 5-111(a) is the better answer. The beneficiary's losses here are economic. The per se rule permits the advisor to estimate its risks. Under a per se rule, damages are not speculative or difficult to prove, and the beneficiary alone, not its suppliers, employees, or anyone else can recover. ${ }^{121}$ The duties run to the beneficiary alone.

\section{APPLICANT CAUSES OF ACTION}

\section{A. For Wrongful Dishonor}

When the issuer dishonors wrongfully, it is not only the beneficiary that incurs losses. The applicant may also incur them. The issuer's dishonor may render the applicant in breach of the underlying contract.

120. See U.C.C. § 5-111 (2002).

121. Id. $\S 5-111$ (a). 
The "underlying contract" in a commercial letter of credit is, as the illustration in note five supra indicates, ${ }^{122}$ a contract for the sale of goods. If that contract specifies "payment by letter of credit," the issuer's dishonor of the beneficiary's complying presentation renders the applicant, the buyer of the goods, liable for the sales price. ${ }^{123}$ In a standby credit transaction, payment under the credit may well be an interest or principal payment on a bond or similar obligation. In both cases, the applicant may incur damages-loss of goods for which it must cover in the commercial transaction and acceleration of principal indebtedness in the standby transaction. Both can lead to consequential damages-damage to reputation in an industry in the commercial transaction with attendant refusal of suppliers to deal and embarrassment or insolvency in the standby transaction.

The Article 5 remedy section stipulates that such a damaged applicant may recover his damages, including incidental damages, less expenses saved as a consequence of the breach, but not consequential damages. ${ }^{124}$ The breach, of course, is not a breach of the letter of credit but of the application agreement-a garden variety contract. Thus the Article 5 rule is puzzling, for, apart from the fee that the applicant paid the issuer for issuing the credit, consequential damages are really the only damages the applicant will incur. ${ }^{125}$ The issuer will not debit the applicant's account. There will be no payment under the credit and no corresponding reimbursement obligation. Any fee that the applicant has paid to the issuer ought to be returned, but that fee will almost always be small relative to the applicant's consequential losses. The official comments to the remedies section are unhelpful, and the measure of the applicant's non-consequential damages remains obscure. ${ }^{126}$

It is not obscure, however, that under Article 5 the applicant should not recover consequential damages. ${ }^{127}$ If a standby credit applicant uses a standby to make direct payments on a bond, the applicant may sustain serious consequential damages when the issuer dishonors the standby wrongfully. The applicant may lose financially attractive credit terms under the bond. It may have to refinance at higher rates and may incur penalties, attorney's fees and other expenses due the bondholder. In those circumstances, however, though the applicant may, under section 5-

122. See supra note 5.

123. See U.C.C. § 2-325(c) (2003).

124. See U.C.C. $\$ 5-111(\mathrm{~b})(2002)$.

125. Id.

126. See U.C.C. \$ 5-111 cmt. 4 (2004).

127. U.C.C. $\$ 5-111$ (2004). 
111(b) recover the fee it paid the issuer, it may not recover the serious consequential damages.

Application of tort causes of action, for negligent evaluation of the beneficiary's documents, say, would relieve the harshness of that rule. Yet application of tort law here violates the Article 5 policy of protecting financial institutions from liability for the unlimited damages that tort law countenances. Pre-Article 5 commentary, government regulations, and case law make it abundantly clear that the policy against imposing consequential damages on banks is not the product of legislative indifference or oversight. ${ }^{128}$ Clearly, the applicant's losses are economic, and application of the economic loss doctrine is in order.

Applicant efforts to recover loss when the issuer wrongfully dishonors have had limited success. Notwithstanding the clear implication in section 5-111(b) that applicants may sue for wrongful dishonor, reported cases involving applicant claims for damages occasioned by wrongful dishonor are rare. Given the fact that the applicant is not a party to the letter of credit, courts appear to be disinclined to sustain such causes of action. ${ }^{129}$

\section{B. For Wrongful Honor}

While applicant claims for wrongful dishonor are not evident in the cases, applicant claims for wrongful honor arise. These cases, also sanctioned by Article $5,{ }^{130}$ eschew any per se rule, however, that would allow the applicant to recover the amount of the draw per se. Instead they force the applicant to prove that the issuer's mistaken payment causes the

128. "If the banks were liable for consequential damages, the added liability would have to be directly reflected in commercial credit rates, with the result that the skillful and prudent members of the mercantile community would be paying, through increased rates, for the ineptitude or recklessness of marginal operators." HENRY HARFIELD, BANK CREDITS AND ACCEPTANCES 109 (5th ed. 1974). There is no hint in the pre-code cases that anything other than the face amount of the credit plus interest are recoverable. See generally NEW YORK LAW REVISION COMM'N, STUDY OF UNIFORM COMMERCIAL CODE, ARTICLE 5-LETTERS OF CREDIT 131-37 (1955). The face-amount rule, moreover, has no application in the wrongful dishonor setting, for the applicant has not lost that amount, which should remain in its deposit account, the issuer not having paid the beneficiary.

129. See, e.g., Rival 1981-IV Drilling Program, Ltd. v. Guar. Bank \& Trust, 732 P.2d 1233 (Colo. Ct. App. 1986); Interchemicals Co. v. Bank of Credit \& Commerce Int'1, 635 N.Y.S.2d 194 (N.Y. App. Div. 1995); cf. Native Alaskan Reclamation \& Pest Control, Inc. v. United Bank Alaska, 685 P.2d 1211 (Alaska 1984) (ambiguous case suggesting that applicant had standing to sue issuer for wrongful dishonor).

130. See U.C.C. $\$ 5-111$ (b) (2002). 
applicant loss. ${ }^{131}$ Applicants might resort to breach of the application agreement, a breach of contract action rather than the statutory cause of action in section 5-111(b), yet for courts to countenance that breach of contract cause of action with its possibility of consequential damages clearly violates the plain intention of Article 5 to deny the applicant recovery of consequential damages. ${ }^{132}$

This disparate treatment, (1) a per se rule for beneficiary claims against issuers for wrongful dishonor and (2) a "damages proved" rule for applicant claims for wrongful honor or wrongful dishonor, is consistent with the fact that the former are claims for breach of the letter of credit undertaking, while the latter are claims for breach of contract, the application agreement. But, the disparate treatment is inconsistent with the fact that the issuer is in no better position to foresee damages in one over the other. Nonetheless, for the purposes of measuring the fit of the economic loss doctrine in these transactions, both rules support its application. The per se rule reflects legislative concern that damages not be unlimited and that litigation over them not be protracted. It is a simple rule, easy to determine and easy to apply.

The per se rule, though inexact in measuring the beneficiary's actual damages, allows easy determination of a figure that approximates the damages the beneficiary suffers. There is no amount in the letter of credit transaction that approximates the applicant's losses, however, so a per se rule for applicant claims for wrongful dishonor cannot supply a valid damages measure. The "damages proved" rule is a breach of contract damages rule. As a typical contract damages remedy, it applies without regard for negligence or bad faith; furthermore, it does not allow recovery of exemplary damages, ${ }^{133}$ and the losses it covers are economic losses.

131. Id. (" $[\mathrm{T}]$ he applicant may recover damages resulting from the breach, including incidental but not consequential damages, less any amount saved as a result of the breach.").

132. See id. (emphasis added) ("[I]ncluding incidental but not consequential damages[.]").

133. Exemplary damages are typically not recoverable in breach of contract actions. "No matter how reprehensible the breach, damages are generally limited to those required to compensate the injured party for lost expectation, for it is a fundamental tenet of the law of contract remedies that an injured party should not be put in a better position than had the contract been performed." See E. ALAN FARNSWORTH, CONTRACTS 760 (4th ed. 2004) (citation omitted). The rule recognizes that the law does not discourage efficient contract breach and that awards of punitive or exemplary damages undermine that principle. Id. at 737 . The UCC generally denies exemplary damages. See U.C.C. § 1305(a) (2004). 
In short, the stated Article 5 remedies for applicant recovery for breach of the application agreement are purely economic. ${ }^{134}$ Article 5 limits damages in the same way that the doctrine limits them. There is no statutory justification, then, to supplement the Article 5 remedies with tort remedies.

\section{For Breach of Warranty}

Applicants complain when the beneficiaries' draws on the issuer are fraudulent, include forged documents, or constitute a breach of the underlying contract between the applicant and the beneficiary. ${ }^{135}$ Thus, when a beneficiary presents a forged bill of lading; a seriously false, i.e., fraudulent, ${ }^{136}$ inspection certificate; or draws for amounts in excess of those due under the contract between the beneficiary and the applicant, the applicant is necessarily damaged and merits a cause of action against the beneficiary for losses occasioned by the issuer's payment against such draws. Although applicants often style these actions in any variety of ways, these complaints sound in warranty. Section 5-110 creates such warranties when the issuer pays the beneficiary in such cases. ${ }^{137}$

134. See U.C.C. \& 5-111(b) (2002).

135. The text does not address multi-party letter of credit transactions that feature an applicant for the credit that is not in privity with the issuer. Those cases often involve a corporate cognate or principal of the party for whose account the credit issues. The cognate or other interested party lends its credit to the account party by applying for the credit. See, e.g., 5027-Atria Builders, L.L.C. v. Morgan 32 Holdings, L.L.C., 922 N.Y.S.2d 364 (N.Y. App. Div. 2011); One Step Up, Ltd. v. Webster Bus. Credit Corp., 925 N.Y.S.2d 61 (N.Y. App. Div. 2011); In re Valley Vue Joint Venture, 123 B.R. 199 (Bankr. E.D. Va. 1991). Sometimes the account party applies for the credit, and the cognate or the principal guarantees the account party's reimbursement obligation. See, e.g., McCaughey v. Bank of Am., N.A., 279 F. App. 794 (11th Cir. 2008). Article 5 anticipates these transactions. See U.C.C. \$5-102(a)(2) (2002). First it defines "applicant" to include both the party in privity with the beneficiary (the account party) and the party whose credit standing prompts the issuer to issue the credit. Id. Second, in the comments to the remedy section, the drafters made it clear that the party not in privity benefits from the warranty. U.C.C. $\S 5-110 \mathrm{cmt} .2$ (2002). The warranty section's application is not limited to those multi-party transactions as comment 3 to the warranty section makes clear. Id at cmt. 3. For thoughtful and comprehensive treatment of this and related questions under the warranty section, see Richard Dole, Warranties by Beneficiaries of Letters of Credit Under Revised Article 5 of the UCC: The Truth and Nothing but the Truth, 39 Hous. L. REv. 375 (2002). See also discussion infra note 148.

136. Fraud in Article 5 does not arise in the event of technical misstatements or the like. See U.C.C. $\$ 5-109$ (a) (2002). Article 5 actions are fraudulent only if they are "materially" fraudulent. Id. Such fraud does not arise when the beneficiary has a colorable right to draw but only if the draw is "plainly" a violation of the underlying contract or if the beneficiary has no "colorable" right to draw. See id. at cmt. 1.

137. See U.C.C. § 5-110(a) (2002). 
Regrettably, disappointed applicants, for whatever reasons, are inclined to fashion causes of action other than the warranty causes, resorting instead to actions in third-party-contract-beneficiary theory, ${ }^{138}$ common-law fraud ${ }^{139}$ negligent misrepresentation, ${ }^{140}$ breach of contract, negligence, conversion, and unjust enrichment. ${ }^{141}$ The breach of warranty cause of action is sometimes broader than these causes of action and sometimes narrower. It broadens liability, for example, by permitting those who are not party to any contract with the beneficiary but who suffer loss by virtue of the warranty breach to sue, ${ }^{142}$ and reduces the burden of showing a cause of action for common-law fraud. It narrows liability by rejecting any per se damages rule and forbidding exemplary damages. A breach of warranty case under the 1965 version of Article 5 awarded judgment for the plaintiff for the full amount of the credit - a per se rule, for the actual damages were never proved. ${ }^{143}$ The comments to section 5-110 make it clear that the per se rule does not apply ${ }^{144}$ and that breach of warranty damages under UCC Articles 2, 3, and 4 might provide courts with helpful analogies. The comments also

138. E.g., Leica Geosystems, AG v. Jefferson Cnty., 325 F. App. 816 (11th Cir. 2009) (applicant claiming to be third party beneficiary of underlying contract and also claiming for breach of the letter of credit warranty).

139. E.g., Sewchez Int'l Ltd. v. CIT Grp./Commercial Servs., 359 F. App. 722 (9th Cir. 2009).

140. E.g., Instituto Nacional De Comercializacion Agricola (Indeca) v. Cont'l Ill. Nat'l Bank \& Trust Co. of Chi, 530 F. Supp. 279 (N.D. Ill. 1982).

141. For a case in which the applicant claimed against the beneficiary in a wrongful draw setting for conversion, breach of contract, negligence, and unjust enrichment, see Krause v. Stroh Brewery Co., 240 F. Supp. 632 (E.D. Mich. 2002). Cf. Arrowood Indem. Co. v. Assurecare Corp., No. 11 CV 5206, 2011 U.S. Dist. LEXIS 146095 (N.D. Ill. Dec. 15, 2011) (suit for breach of contract, conversion, fraud, unjust enrichment, and negligence); Atria Builders, 922 N.Y.S.2d 364 (suit for wrongful draw, styled as one for conversion or money had and received). For numerous additional cases, see 1 DoLAN TREATISE, supra note 50, at ๆ 6.07[1] n.587.

142. See U.C.C. $\$ 5-110 \mathrm{cmt}$. 2 (2002). For an illustrative case, see Alstom Power, Inc. v. RMF Indus. Contracting, Inc., 418 F. Supp. 2d 766 (W.D. Pa. 2006). One plaintiff ignoring the warranty section was able to recover but only after meeting the heavy burden of showing that he was an intended third-party beneficiary of the underlying contract. Id. See also Centennial Mtg., Inc. v. Blumenfeld, 745 N.E.2d 268 (Ind. Ct. App. 2001). For cases in which the third-party beneficiary argument failed for want of proof, see 1 DOLAN TREATISE, supra note $50, \uparrow 9.02[3]$, at $9-15 \mathrm{n} .79$. For one case holding squarely that a third-party beneficiary may sue on the credit, see Turquoise Props. Gulf, Inc. v. IberiaBank, No. 09-00272KD-N, 2009 U.S. Dist. LEXIS 97795 (S.D. Ala. Oct. 8, 2009).

143. Mellon Bank, N.A. v. Gen. Elec. Credit Corp., 724 F. Supp. 360 (W.D. Pa. 1989) The plaintiff in Mellon Bank was the issuer, not the applicant. Id. That distinction is unimportant, however.

144. See UCC $\S 5-110 \mathrm{cmt} .3(2002)$. 
acknowledge, without apology, that sometimes a beneficiary's breach of this warranty will yield damages of "zero.", 145

The references to other articles are helpful. Article 2, the UCC's Sales article, was the locus for development of the economic loss doctrine. Generally, the economic loss doctrine denies recovery of such damages unless they are foreseeable. ${ }^{146}$ The warranty sections in Articles 3 and 4, moreover, limit recovery for breach of warranty to actual loss suffered, not to exceed the amount of the item, plus expenses and interest. ${ }^{147}$ In short, the warranties of the referenced articles are consistent with application of the economic loss doctrine in Article 5 warranty litigation. They either adopt the doctrine or fashion loss limits that reflect the policies of the doctrine identified in Part III above: keeping loss recovery to damages that are foreseeable.

\section{ISSUER AND THIRD PARTY CAUSES OF ACTION}

Issuers, beneficiaries, and applicants ${ }^{148}$ are essential parties to the letter of credit transaction $a b$ initio. ${ }^{149}$ As the transaction proceeds, other

\section{Id.}

146. This is the rule of Hadley v. Baxendale, 156 Eng. Rep. 145 (1854). For an opinion that invokes it in the commercial payments setting and rehearses its policy origins, see Evra Corp. v. Swiss Bank Corp., 673 F.2d 951 (7th Cir. 1982), cert. denied, 103 U.S. 377 (1982).

147. See U.C.C. $\S \S 3-416(b), 3-417(b), 4-207(b)$, and 4-208(b) (2002). Not all cases observe these limitations, however. In 1/2 Price Checks Cashed v. United Auto. Ins. Co., 344 S.W.3d 378, 389 (Tex. 2011), the court ruled that an action on an improperly dishonored check is a suit for breach of a contract and, therefore, that attorney's fees were recoverable even though Article 3 does not provide for such recovery. In Atria Builders, 922 N.Y.S.2d 364, the court held that an action by an applicant against the beneficiary for wrongful dishonor of a letter of credit was an action in contract subject to contract remedies even though the applicant was not in privity with the beneficiary. To characterize that action as one for breach of the Article 5 warranty is surely superior analysis. See authority cited infra note 148 .

148. The term "applicant" includes not just the buyer in the illustration set out in note 5 supra, but also parties that arrange the letter of credit for the buyer. See U.C.C. § 5102(a)(2) (2002). Whether guarantors of the applicant's reimbursement obligation have standing to make claims for issuer misbehavior is a matter, one would think of assignment law or subrogation. Cf. U.C.C. $\$$ 5-117 (2002) (Article 5 subrogation section that does not address subrogation for such guarantors). It is clear that all applicants benefit from the warranty section, including those who are not in privity with the beneficiary in the underlying transaction. The official comment makes protection of such applicants the "primary" purpose of the section. U.C.C. $\$ 5-110 \mathrm{cmt}$. 2 (2002). See also In re Texas Commercial Energy, 607 F.3d 153 (5th Cir. 2010) (same). But cf. 5027-Atria Builders, L.L.C., 922 N.Y.S.2d 364, 365 (N.Y. App. Div. 2011) (looking to the underlying contract to determine liability rather than invoking the warranty section in an 
parties make their appearance. They are (1) banks other than the issuer or confirmer and (2) investors, a term that may include banks, all of whom take an interest in obligations that arise post-issuance. Parts V and VI address beneficiary and applicant remedies respectively. This Part deals with issuer claims and those of parties who appear in the transaction after the credit issues.

\section{A. Banks in Their Various Letter of Credit Transaction Roles}

The letter of credit issuer is almost always a bank. ${ }^{150}$ Issuers file claims against their customers when the customers breach the application agreement, usually by failing to reimburse the issuer post-payment or by failing to provide collateral or funds pre-payment if the application agreement so provides. These claims rest on contract law, are for economic losses, and fit neatly into the economic loss doctrine, just as the applicant's claims against the issuer, discussed in Part VI above, fit into it. In any event, they are beyond the scope of this paper, which addresses letter of credit transaction claims, not breach of contract claims.

The letter of credit issuer does make claims that arise out of the letter of credit relationships. Those claims are for breach of the letter of credit warranties described in section 5-110 of the UCC. Regrettably, cases involving these claims may miscast them as suits for "wrongful draw,"

action brought by an applicant against the beneficiary with whom the applicant was not in privity).

149. It is possible, though rare, for letter of credit transactions to involve only two parties. An issuer may cause a letter of credit to issue to itself as beneficiary. See, e.g., Nat'l Bank of N. Am. v. Alizio, 482 N.E.2d 907 (N.Y. 1985). An issuer may issue a credit on its own behalf. See U.C.C. $\S 5-102(a)(10)$ (2002). There is nothing in letter of credit law to prevent an applicant to cause an issuer to issue a credit to the applicant as beneficiary, an arrangement that formerly was common as a "traveler's letter of credit." See, e.g., Ufitec, S.A. v. Trade Bank \& Trust Co., 209 N.E.2d 551, 551 (N.Y. 1965).

150. Non-banks may issue letters of credit, but many that do are financial institutions. Occasionally, a beneficiary will take a credit issued by an industrial firm, mortgage broker, or the like, which issues the credit for its own account, sometimes with predictable and untoward results. See Gulf Bank KSC v. Mitsubishi Heavy Indus., Ltd. (No. 2), 2 Lloyd's L. Rep. 145 (C.A.) (1994) (involving industrial concern that wrongfully dishonored letter of credit); Barclays Bank D.C.O. v. Mercantile Nat'1 Bank, 481 F.2d 1224 (5th Cir. 1973) (involving mortgage broker issuer that became insolvent). For a case in which the court derided credits issued by the issuer for it own account as "mere pieces of paper," see Peter Pan Mgmt. Pty. Ltd. (in liquidation) v. Capital Fin. Corp. (Australia) Pty. Ltd., (Unreported, Supreme Court of Victoria, Commercial \& Equity Division, July 5, 2001). 
breach of contract, replevin, conversion, and unjust enrichment, ${ }^{151}$ all the while ignoring the fact that the beneficiary's conduct breaches the Article 5 warranties due the issuer. ${ }^{152}$ A more rational approach would limit claims to breach of warranty by dismissing these various non-Article 5 claims. A fortiori, courts should also dismiss tort claims with the exception of those claims that involve material fraud, or other intentional and dishonest conduct.

There is authority that the economic loss doctrine does not displace actions for fraud and intentional misrepresentation. Fraud is a problem no less in letter of credit transactions than in other commercial activity, and it has caught the attention of courts and legislators, who have fashioned law over more than sixty years to deal with it. Often, applicants do not want the issuer to pay the beneficiary, and they sometimes claim the beneficiary's demand for payment is fraudulent. ${ }^{153}$ If the court entertains that defense by investigating the facts, it will delay payment of the credit pending the outcome of the litigation that investigation entails. Delay in payment destroys the credit, however, for it forces the beneficiary to litigate before it is paid and transmutes the letter of credit (a pay-now, argue-later device) into a bond (an arguenow, pay-later-device). ${ }^{154}$

In virtue of that threat, courts and the UCC have fashioned limits on the fraud defense. Chief among them, and the limit pertinent to this discussion, is the feature of letter of credit law that limits fraud defenses to those that are what the UCC calls "letter of credit" fraud.

The leading case is from a New York trial court, which held that courts cannot ignore fraud even though fraud claims pose serious threats

151. See, e.g., Krause, 240 F. Supp. $2 \mathrm{~d}$ at 634 (claims for conversion, breach of contract, unjust enrichment, promissory estoppel, and negligence but not for breach of warranty); In re Enron Corp., 59 U.C.C. Rep. Serv. 2d 359 (Bankr. S.D.N.Y. 2006) (claim for unjust enrichment but not breach of warranty); Alhadeff v. Meridian on Bainbridge Island, LLC, 185 P.3d 1197 (Wash. Ct. App. 2008) (common law claims sounding in contract and tort) (case reversed, however the claims remained the same); Alhadeff v. Meridian on Bainbridge Island, LLC, 220 P.2d 1214 (Wash. 2009) (en banc).

152. See, e.g., Bank of Joliet v. Firstar Bank Milwaukee, N.A.A., No. 96 C 1145, 1997 WL 619875 (N.D. Ill. Sept. 30, 1996) (issuer failing to sue for breach of warranty, relying instead on applicant's assignment of a breach of underlying contract claim); United Trade Assocs. Ltd. v. Dickens \& Matson (USA) Ltd., 848 F. Supp. 751 (E.D. Mich. 1994) (beneficiary's more burdensome suit for common law fraud when breach of warranty claim would have been appropriate).

153. Letter of credit law treats claims of forgery in one of the documents the beneficiary presents in the same way that it treats the fraud defense. If reported cases are any indication, however, applicants seldom raise the forgery defense.

154. See Eakin v. Cont'l Ill. Nat'l Bank \& Trust Co., 875 F.2d 114, 116 (7th Cir. 1989) (characterizing the credit as a pay-now, argue-later device in contrast to an argue-now, pay-later device). 
to the all-important independence principle of letter of credit law. ${ }^{155}$ After acknowledging the serious threat that the fraud defense poses for the independence principle, the New York court held, however, that the court should stop payment only if the fraud is clear and egregiousshipping rubbish instead of valuable merchandise. ${ }^{156}$ In addition, by virtue of the posture of the matter in the New York case, the court faced a fraud defense argument that was proved. ${ }^{157}$ Article 5 and letter of credit case law following the lead of the New York trial court have cabined the fraud defense by limiting it to cases of forgery or "material" fraud, 158

155. Sztejn v. J. Henry Schroder Banking Corp., 31 N.Y.S.2d 631 (N.Y. Sup. Ct. 1941).

156. Id. at 635 .

157. Id. at 633. The matter came to the court's attention in Sztejn on a motion to dismiss, and the court was forced to accept the fraud, being well pleaded, as established. Id. That feature of the Sztejn case has prompted U.K. courts to state the rule as one that applies only if the fraud is "established," a significantly high burden for applicants attempting to stop payment in the U.K. courts. See, e.g., Banco Santander SA v. Banque Paribas, (2000) All ER (D) 246 (Ct. App. Civ. Div.); Cairn Energy PLC v. Royal Bank of Scotland, PLC, (2000) ScotSC 325; Balfour Beatty Civil Eng'g v. Technical \& Gen. Guar. Co. Ltd., (1999) 68 ConLR 180 (Ct. App. Civ. Div.). Most fraud issues arise when the applicant seeks to stop payment under the credit, and the issue before the courts is whether it is appropriate to grant injunctive relief when the fraud, though well pleaded, may be a matter of dispute. The fraud exception to the independence principle has generated a rich body of commentary in the U.S. and elsewhere. See, e.g., Michelle Kelly-Louw, Selective Legal Aspects of Bank Demand Guarantees (2008) (South Africa), available

http://uir.unisa.ac.za/xmlui/bitstream/handle/10500/1350/thesis.pdf?sequence $=1 ; \quad$ Ali Malek, Jack: Documentary Credits 245-301 (4th ed. 2009) (U.K.); MATTI KuRKELA, LETTERS OF CREDIT AND BANK GUARANTEES UNDER INTERNATIONAL TRADE LAW 173-210 (2d ed. 2007) (Finland); Agasha Mugasha, THe Law of LetTers of Credit and BanK Guarantees 136-194 (2003) (Australia); XIang GaO, The Fraud Rule in the LaW OF LetTers of CrediT (2002) (China); I Dolan Treatise, supra note 50, at 9 T 7.03, 7.04, 11.05 (U.S.). Article 5 addresses the issue in U.C.C. $\$ 5-109$ (2002).

158. See U.C.C. $\$ 5-109$ (a) (2002). There is a rich body of case law making it clear that technical misstatements in a beneficiary's presentment to an issuer do not constitute material fraud. Thus, a certification that sums are due, even though the parties are disputing the amount due, is not fraud. See Philipp Bros., Inc. v. Oil Country Specialists, Ltd., 787 S.W.2d 38 (Tex. 1990). Nor, according to some courts, is it fraud for a beneficiary to draw on a credit for purposes not stated in the credit but agreed to elsewhere. See W. Va. Housing Dev. Fund v. Sroka, 415 F. Supp. 1107 (W.D. Pa. 1976). Rather than a rule allowing technical fraud arguments to interrupt operation of the independence principle, the purpose of the fraud exception to that principal rule is one of preventing the beneficiary from taking the proceeds of the credit when the beneficiary has no colorable right or no basis in fact to the proceeds. For Judge-as he then wasBreyer's collection of colorful court rulings to this effect, see Ground Air Transfer, Inc. v. Westates Airlines, Inc., 899 F.2d 1269, 1272-73 (1st Cir. 1990). Cf. Peter Ellinger, Fraud in Documentary Credit Transactions, 1981 J. Bus. L. 258, 262 (concluding that 
imposing serious procedural burdens on issuers or applicants seeking to invoke it, ${ }^{159}$ and by creating a cadre of protected parties against whom it is no defense. ${ }^{160}$

This brief summary of the fraud defense sheds light on the subject of fraud claims. Fraud litigation before the issuer honors the credit is anathema to the proper functioning of letters of credit as commercial devices; hence the legislative and judicial resistance to such defenses except in the narrowest of situations. Clearly, fraud claims should arise only after the issuer honors the credit, else the issuer could raise its fraud claim by way of counterclaim and effectively avoid the tethers Article 5 has fashioned to prevent pre-honor litigation of the fraud issue.

Article 5 recognizes post-honor fraud claims. ${ }^{161}$ In fact, it codifies a rule for them in the warranty section, which recognizes fraud as a warranty breach. ${ }^{162}$ Article 5 limits damages for such claims to contract nature damages and acknowledges that sometimes the damages will be less that the amount of the credit and sometimes zero. ${ }^{163}$

It is difficult to conceive of clearer evidence that the legislature does not want fraud claims to include recovery of damages in tort, including exemplary damages. What is more, the policy of the warranty section which includes limitations for fraud claims is also evidence of an intention that parties not be able to avoid easily the limitations on fraud claims by styling the claims as bad faith, deceit, intentional misrepresentation, or the like.

In short, this intentional misbehavior by a beneficiary breaches the warranty. The breach of warranty cause of action should displace the issuer's common law tort actions against the beneficiary in letter of credit litigation.

\section{CONCLUSION}

Article 5 of the Uniform Commercial Code fashions a comprehensive scheme for dealing with the areas of dispute that are most common in letter of credit litigation: claims for wrongful dishonor,

under the U.S. cases, there is fraud only when "the beneficiary acts without any shred of honest belief in his rights"); U.C.C. § 5-109 cmt. 1 (2002).

159. See U.C.C. \$ 5-109(b).

160. See U.C.C. $\S 5-109$ (a)(1)(i), (ii), (iii) \& (iv). See generally Richard Dole, The Effect of UCP 600 Upon UCC Article 5 with Respect to Negotiation Credits and the Immunity of Negotiating Banks from Letter of Credit Fraud, 54 WAYNE L. REV. 735 (2008).

161. See U.C.C. \$ 5-111 (2002).

162. See U.C.C. $\$ 5-110(2002)$.

163. See U.C.C. § $5-111 \mathrm{cmt} .2$ (2002). 
wrongful honor, breach of warranty, and adviser or nominated bank misfeasance.

The legitimate ends of that scheme are fourfold: (1) to simplify and clarify claim resolution and reduce its attendant costs, (2) to promote prompt resolution of outstanding claims through a short statute of limitations, (3) to protect financial institutions and other issuers from liability exceeding the face amount of their undertakings largely by prohibiting tort causes of action, narrowing the scope of bad-faith claims to actual dishonesty, and denying recovery of consequential and exemplary damages, and (4) to discourage frivolous litigation by mandating an attorney's fees award for the party succeeding, be it the claimant or the defendant, in such litigation.

The economic loss, gist of the action, and East River doctrines support the thesis of this article. ${ }^{164}$ More important is the fact that the Uniform Commercial Code's sophisticated allocation of risks and liabilities supports the commercial viability of letter of credit undertakings. Those undertakings are the paradigm of commercial activity, involving underlying contracts and prompt, inevitable payment against the formalistic presentation of complying documents. The sophisticated, non-consumer parties that avail themselves of the letter of credit payment mechanism may protect themselves in their underlying relationships ex ante. Article 5 does not permit ex post reallocation of risk in the letter of credit context. Such reallocation through tort or common law contract causes of action imposes burdens on letters of credit that are beyond the parties' reasonable expectations and that neuter this quintessentially commercial device. Litigation is the bane of the swift, low-priced letter of credit. Article 5 takes account of commercial realities when it fashions a scheme for the lean resolution of disputes arising out of letter of credit activity.

164. Cases finding a comprehensive statutory scheme for recovery for breach of an obligation also support that thesis. See authority cited in text supra note 50. 
